\title{
PENGARUH KETERAMPILAN PROSES SAINS TERHADAP KEMAMPUAN BERPIKIR LOGIS PADA ANAK USIA DINI
}

\author{
${ }^{1}$ Restu Ilma Nurqolbi, ${ }^{2}$ Arifah A Riyanto, ${ }^{3}$ Ririn Hunafa Lestari \\ ${ }^{1}$ IKIP Siliwangi, Jl. Terusan Jendral Sudirman, Cimahi \\ ${ }^{2}$ IKIP Siliwangi, Jl. Terusan Jendral Sudirman, Cimahi \\ ${ }^{3}$ IKIP Siliwangi, Jl. Terusan Jendral Sudirman, Cimahi \\ 1ilmarestu@gmail.com, ${ }^{2}$ arifahastim@yahoo.com, ${ }^{3}$ ririnhunafa@ikipsiliwangi.ac.id
}

\begin{abstract}
One aspect of development that can be developed in early childhood through the field of early childhood education is the aspect of cognitive development. In the cognitive aspect there are capabilities that must be developed, namely the ability to think logically which can be developed through science learning methods for early childhood, one of them through science process skills, where children will learn experiments, explore, and identify the surrounding environment to build their own knowledge with curiosity high so that later it will be useful in his adult life. This research uses quantitative research methods using quasi-experimental research using a nonquivalent group design research design. This study aims to determine the effect of science process skills on children's logical thinking skills. Based on the results of the study it was found that the average gain of the experimental class was 76.14 while the average gain value of the control class was 5.60, which meant that the use of science process skills was effective to improve the logical thinking skills of early childhood. Therefore, this research is recommended to early childhood educators so that science process skills can be used as one of the lessons to improve children's logical thinking skills.
\end{abstract}

Keywords: ability to think logically, process science skills

\begin{abstract}
Abstrak
Salah satu aspek perkembangan yang dapat dikembangankan pada anak usia dini melalui bidang pendidikan anak usia dini adalah aspek perkembangannya kognitif. Dalam aspek kognitif terdapat kemampuan yang harus dikembangkan yaitu kemampuan berpikir logis yang dapat dikembangkan melalui metode pembelajaran sains untuk anak usia dini salah satunya melalui keterampilan proses sains, dimana anak akan belajar eksperimen, bereksplorasi, dan mengidentifikasi lingkungan sekitar untuk membangun suatu pengetahuannya sendiri dengan rasa keingintahuannya yang tinggi sehingga nantinya akan bermanfaat pada masa dewasanya. Penelitian ini menggunakan metode penelitian kuantitatif dengan menggunakan jenis penelitian kuasi eksperimen dengan menggunakan desain penelitian kelompok kontrol non-ekuivalen (the nonequivalent grup design). Penelitian ini bertujuan untuk mengetahui pengaruh keterampilan proses sains terhadap kemampuan berpikir logis anak. Berdasarkan hasil penelitian diperoleh bahwa rata-rata nilai gain kelas eksperimen 76,14 sedangkan rata-rata nilai gain kelas kontrol 5,60 yang artinya penggunaan keterampilan proses sains efektif untuk meningkatkan kemampuan berpikir logis anak usia dini. Maka dari itu, penelitian ini direkomendasikan kepada pendidik anak usia dini agar keterampilan proses sains dapat dijadikan sebagai salah satu pembelajaran untuk meningkatkan kemampuan berpikir logis anak.
\end{abstract}

Kata Kunci: kemampuan berpikir logis, keterampilan proses sains 


\section{JURNAL GERIA}

ISSN : 2614-6347 (Print) 2614-4107 (Online)

\begin{tabular}{l|l|l} 
Vol.2 & No.5 & September 2019 \\
\hline
\end{tabular}

\section{PENDAHULUAN}

Pendidikan anak usia dini sangat penting diberikan kepada anak sebagai bentuk penyelenggara yang berfokus pada peletakkan dasar bagi pembentukan kepribadian manusia secara utuh, yang ditandai dengan perkembangan karakter yang positif, budi pekerti luhur, pandai dan terampil. Pendidikan untuk anak usia dini pada dasarnya meliputi seluruh upaya dan tindakan yang dilakukan oleh orang tua, guru dan masyarakat sebagai pendidik melalui proses perawatan, pengasuhan, serta pemberian pendidikan dengan menciptakan kondisi lingkungan yang dapat mengeksplorasi pengalaman dan memberikan kesempatan kepada anak untuk mengetahui dan memahami pengalaman belajar yang diperolehnya melalui proses pengamatan, meniru, dan melakukan kegiatan eksperimen yang dilakukan secara berulang-ulang dan melibatkan seluruh potensi dan kecerdasan anak usia dini. (Mursid, 2015; Mursid, 2016)

Menurut Susanto (2011, hal. 12) menyatakan bahwa munculnya potensi anak usia dini memang bergantung pada stimulus yang diberikan. Karena itu, wajib bagi orang tua atau pendidik untuk menggali sekaligus mengembangkan potensi anak sejak dini. Makin dini anak menerima stimulasi akan makin baik. Seluruh potensi anak usia dini yang harus dikembangkan meliputi beberapa aspek yaitu aspek kognitif, bahasa, fisik motorik, sosial emosional dan moral (Susanto, 2011, hal.48).

Aspek perkembangan kognitif mempunyai peranan sangat penting bagi keberhasilan anak dalam belajar, karena sebagian besar aktivitas dalam belajar selalu berhubungan dengan masalah mengingat dan berpikir (Muslihuddin \& Agustin, 2008, hal. 11). Pada dasarnya mengembangkan perkembangan kognitif dimaksudkan agar anak usia dini mampu melakukan eksplorasi terhadap dunia sekitar melalui panca inderanya, sehingga dengan pengetahuan yang didapatkannya tersebut anak-anak dapat melangsungkan hidupnya dan menjadi manusia yang utuh sesuai kodratnya sebagai makhluk Tuhan yang harus memberdayakan apa yang ada di dunia untuk dirinya dan orang lain. Adapun proses kognitif meliputi berbagai aspek, seperti persepsi, ingatan, pikiran, simbol, penalaran, dan pemecahan masalah.

Hurlock (dalam Susanto, 2011) berpendapat bahwa untuk membuat anak kecil mengerti akan lebih baik jika dikenalkan berbagai konsep-konsep menjadi konkret dan realistis. Pembelajaran untuk anak usia dini harus diberi pemahaman melalui contohcontoh nyata, peragaan langsung, dan dikemas melalui bermain. Dengan cara ini, maka secara tidak langsung mereka dapat menerima apa yang diajarkan kepada mereka. Perkembangan kognitif menunjukkan pada proses dan produk dari dalam akal pikiran, daya pikir dan cara berpikir logis manusia yang membawanya untuk tahu. Berdasarkan pernyataan Mursid (2015, hal. 9), daya pikir atau berpikir logis disebut juga sebagai kemampuan seorang anak usia dini untuk mengamati, melihat hubungan-hubungan, kegiatan yang megakibatkan seorang anak usia dini memperoleh pengetahuan baru yang banyak didukung oleh kemampuannya bertanya.

Menurut Yulianti (2010) jika ingin anak-anak kita mempunyai kinerja yang baik disekolah lanjutan, maka anak usia dini hendaknya dibiasakan bereksperimen sains, jika tidak, berarti guru mempersulit anak mengenali sains untuk kehidupan selanjutnya. Sains adalah produk dan proses (Yulianti, 2010 : 18). Menurut Nugraha (2008, hal. 125) secara teoritis anak usia dini usia dini seyogyanya memiliki keterampilan proses sains yang memadai seperti 


\section{JURNAL GERIA}

ISSN : 2614-6347 (Print) 2614-4107 (Online)

Vol.2 | No.5 | September 2019

keterampilan mengobservasi meliputi mengidentifikasi ciri suatu benda, mengidentifikasi perbedaan dan persamaan benda, mencocokan gambar dengan tulisan, mengurutkan dan memberikan uraian tentang benda dan peristiwa tertentu.

Selain itu, dalam keterampilan menggolongkan anak usia dini diharapkan mampu menggolongkan dan mengamati persamaan, perbedaan dan hubungan berdasarkan kesesuaian dengan tujuan. Pada keterampilan mengkomunikasikan anak usia dini diharapkan mampu menyampaikan sesuatu baik secara lisan maupun tulisan, sedangkan dalam keterampilan memprediksi anak usia dini diharapkan mampu membuat dugaan berdasarkan pola-pola tertentu (sebab-akibat) suatu peristiwa berdasarkan pola. Menurut Conant, Fisher (dalam Mursid, 2015) mengartikan sains sebagai suatu kumpulan pengetahuan yang diperoleh dengan menggunakan metode pengamatan dengan penuh ketelitian. Kaitannya dengan program pembelajaran sains untk anak usia dini, sains dapat dikembangkan menjadi tiga substansi mendasar, yaitu pendidikan dan pembelajaran sains yang memfasilitasi penguasaan proses sains, penguasaan produk sains, serta program yang memfasilitasi pengembangan sikap sains. Pentingnya pengembangan keterampilan proses sains pada anak usia dini dapat memberikan berbagai pengalaman yang bermakna bagi anak sehingga akan dibawa oleh anak selama hidupnya.

Berdasarkan hasil obsevasi awal diperoleh informasi tentang kondisi keterampilan proses sains anak kelompok B masih jauh dari harapan. Seperti pada keterampilan proses sains mengamati, mengklasifikasikan, membuat kesimpulan dan mengkomunikasikan menunjukkan hasil yang rendah. Mengetahui adanya kondisi tersebut peneliti mencoba mendeteksi apa penyebab ketidaktercapaian tujuan tersebut antara lain disebabkan cara penerapan pembelajaran sains hanya sekedar kumpulan teori saja dan proses pembelajaran masih menggunakan metode ceramah dan kurang bervariasi, kurangnya lingkungan yang melibatkan anak dalam kegiatan keterampilan proses sains, proses pembelajaran masih kaku dan kurang menarik minat anak untuk mengikuti kegiatan, sehingga anak usia dini khususnya terlihat jenuh dengan pembelajaran yang terjadi sekarang ini, yang akibatnya anak kurang aktif dalam berpikir sehingga anak tidak memiliki sifat berpikir logis.

sebagai suatu proses untuk memperoleh pengetahuan. Rangkaian proses yang dilakukan dalam kegiatan sains tersebut, saat ini dikenal dengan sebutan metode ilmiah.

Secara teoritis anak usia dini usia dini seyogyanya memiliki keterampilan proses sains yang memadai seperti keterampilan mengobservasi meliputi mengidentifikasi ciri suatu benda, mengidentifikasi perbedaan dan persamaan benda, mencocokan gambar dengan tulisan, mengurutkan dan memberikan uraian tentang benda dan peristiwa tertentu (Nugraha. 2008, hal. 125). Keterampilan menggolongkan anak usia dini diharapkan mampu menggolongkan dan mengamati persamaan, perbedaan dan hubungan berdasarkan kesesuaian dengan tujuan. Keterampilan mengkomunikasikan anak usia dini diharapkan mampu menyampaikan sesuatu baik secara lisan maupun tulisan. Keterampilan memprediksi anak usia dini diharapkan mampu membuat dugaan berdasarkan pola-pola tertentu (sebab-akibat) suatu peristiwa berdasarkan pola.

Menurut Mursid (2015, hal 9) menyatakan bahwa daya pikir atau 


\section{JURNAL GERIA}

ISSN : 2614-6347 (Print) 2614-4107 (Online)

Vol.2 | No.5 | September 2019

berpikir logis disebut juga sebagai kemampuan seorang anak usia dini untuk mengamati, melihat hubunganhubungan, kegiatan yang megakibatkan seorang anak usia dini memperoleh pengetahuan baru yang banyak didukung oleh kemampuannya bertanya. Berpikir logis perlu dikembangkan sedini mungkin karena apa yang diperoleh dalam satu periode akan sangat membantu pengembangan berpikir logis pada periode selanjutnya. Menurut Budiningsih (2005, hal. 114) bahwa "kecerdasan logika sering disebut berpikir ilmiah, termasuk berpikir deduktif dan induktif." Menurut pendapat ini bahwa kemampuan berpikir logis merupakan proses berpikir ilmiah dalam menyelesaikan suatu masalah dengan berdasarkan pada kebenaran logika.

Berdasarkan penjelasan diatas dapat disimpulkan bahwa kemampuan berpikir logis pada dasarnya melibatkan kemampuan-kemampuan menganalisis masalah secara logika, menemukan, menciptakan dan menyelidiki sesuatu secara ilmiah yang dimaksudkan agar anak usia dini mampu melakukan eksplorasi terhadap dunia sekitar melalui seluruh panca inderanya, sehingga dengan pengetahuan yang didapatkannya tersebut anak dapat menjadi manusia yang utuh sesuai kodratnya sebagai makhluk Tuhan yang harus memberdayakan apa yang ada di dunia untuk dirinya dan orang lain.

Berdasarkan latar belakang di atas, maka peneliti ingin menguji metode eksperimen sebagai alternatif pembelajaran dalam mengembangkan kemampuan berpikir logis anak usia dini. Dalam upaya mencetak anak usia dini yang baik maka pendidik sangat perlu menggunakan metode pembelajaran yang kreatif dan inovatif agar suasana pembelajaran tidak jenuh dan bosan. Diantara banyak metode yang

$\begin{array}{lrr}\text { dipergunakan } & \text { pendidik } & \text { untuk } \\ \text { meningkatkan } & \text { kecerdasan } & \text { kognitif }\end{array}$ terutama untuk meningkatkan kemampuan berpikir logis anak usia dini yaitu melalui pembelajaran sains melalui keterampilan proses sains, dimana keterampilan proses sains sebagai suatu proses untuk memperoleh pengetahuan. Rangkaian proses yang dilakukan dalam kegiatan sains tersebut, saat ini dikenal dengan sebutan metode ilmiah.

\section{METODE}

Metode penelitian yang digunakan adalah penelitian eksperimen dengan menggunakan jenis kuasi eksperimen dan menggunakan desain penelitian kelompok kontrol non-ekuivalen (the nonequivalent grup design). Kuasi eksperimen ini subjek tidak dikelompokan secara acak, tetapi peneliti menerima keadaan subjek seadanya. Menurut Ruseffendi (2010: 52), pada penelitian ini digunakan dua kelas. Kelas yang pertama sebagai kelas eksperimen yang akan menerima treatment (perlakuan) sebanyak 15 anak diberikan pembelajaran dengan menggunakan keterampilan proses sains, sedangkan kelas yang kedua sebagai kelas kontrol sebanyak 13 anak dengan menggunakan pembelajaran biasa (konvensional). Variabel dalam penelitian ini terdiri dari variabel terikat dan variabel bebas.Variabel terikat dalam penelitian ini adalah kemampuan berpikir logis, sedangkan variabel bebas dalam penelitian ini adalah keterampilan proses sains. Subjek penelitian dalam penelitian ini adalah anak usia dini kelompok B1 dan kelompok B2 dengan rentang usia lima sampai enam tahun. Instrumen penelitian ini menggunakan pedoman observasi penilaian menggunakan skala likert. yaitu : Belum Berkembang (BB), Mulai Berkembang (MB), Berkembang Sesuai Harapan (BSH), Berkembang 


\section{JURNAL GERIA}

ISSN : 2614-6347 (Print) 2614-4107 (Online)

\begin{tabular}{l|l|l|} 
Vol.2 & No.5 & September 2019 \\
\hline
\end{tabular}

Sangat Baik (BSB). Untuk mengungkapkan kejelasan suatu sikap atau sifat yang diteliti. Jawaban responden skor tertinggi bernilai 4 dan skor terendah 1. Misalnya BB (1), MB (2), BSH (3), BSB (4).

\section{HASIL DAN PEMBAHASAN}

Hasil

Pada penelitian ini perlu dilakukan uji normalitas dan uji homogenitas. Berdasarkan perhitungan uji normalitas kolmogrov-smirnov nilai Sig. pada kelompok eksperimen menunjukkan hasil signifikan 0,051 karena 0,051 $>\alpha 0,05$ maka hasil pre test kelompok eksperimen datanya berdistribusi normal. Perhitungan uji normalitas kolmogrov-smirnov nilai Sig pada kelompok kontrol diperoleh hasil signifikan 0,200 karena $0,200>\alpha 0,05$ maka data hasil pre test pada kelompok kontrol berdistribusi normal. Adapun perhitungan uji normalitas kolmogorovsmirnov untuk data post test yang menunjukkan hasil nilai Sig pada kelompok eksperimen menunjukkan hasil signifikan 0,200 karena 0,200> $\alpha$ 0,05 maka hasil post test kelompok eksperimen datanya berdistribusi normal. Perhitungan uji normalitas kolmogrov-smirnov nilai Sig pada kelompok kontrol diperoleh hasil signifikansi 0,116 karena $0,116>\alpha 0,05$ maka data hasil post test pada kelompok kontrol berdistribusi normal. Selain uji normalitas, peneliti menguji data homogenitas pada data pre test dan post test. Berdasarkan hasil data, diperoleh hasil uji homogenitas hasil data pre test kelompok eksperimen dan kelompok kontrol 0,614 karena 0,614 > 00,05 maka data tersebut bervarian homogen. Adapun hasil data post test, berdasarkan hasil SPSS diperoleh hasil uji homogenitas hasil data post test kelompok eksperimen dan kelompok kontrol 1,543 karena 1,543> a 0,05 maka data tersebut bervarian homogen. Hasil penelitian uji normalitas dan homogenitas diperoleh bahwa data berdistribusi normal dan homogen.Oleh karena itu analisis data selanjutnya menggunakan uji t independen.

Tabel 1

Hasil Uji t Independen Data Pre test Kelompok Eksperimen dan Kontrol dengan SPSS 23 (2-tailed)

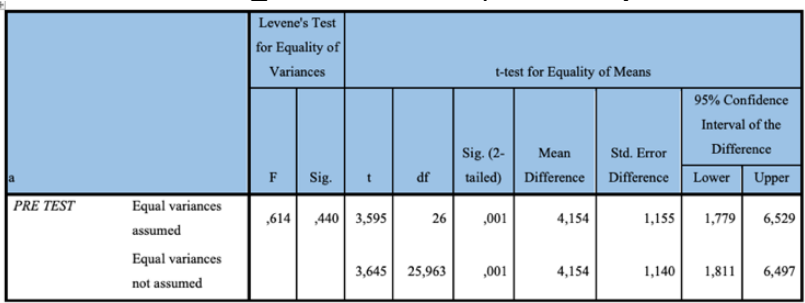

Berdasarkan Tabel 1.1 terlihat bahwa diperoleh nilai sig (2 tailed) adalah 0,001 maka signifikasi satu pihaknya adalah $\frac{0,001}{2}=0,0005$ dengan demikian nilai tersebut kurang dari 0,05 artinya peningkatan kemampuan berpikir logis anak usia dini dengan menggunakan keterampilan proses sains terdapat perbedaan dengan anak yang menggunakan pembelajaran biasa. Hal ini berarti bahwa pada saat pre test (sebelum perlakuan) tingkat kemampuan berpikir logis antara kelompok ekperimen dan kelompok kontrol sudah terdapat perbedaan.

Tabel 2

Hasil Uji t Independen Data Post test Kelompok Eksperimen dan Kontrol dengan SPSS 23 (2-tailed)

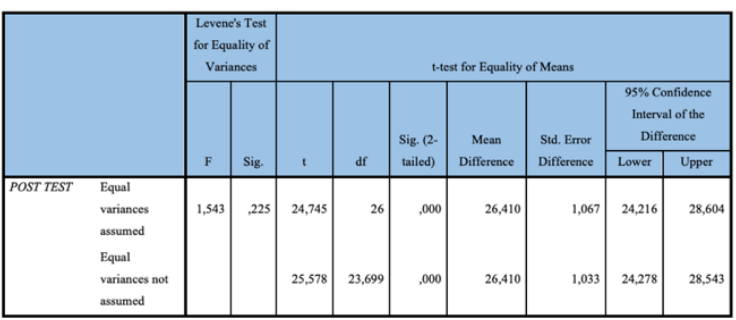

Berdasarkan Tabel 1.2 terlihat bahwa diperoleh nilai sig (2 tailed) adalah 0,000 maka signifikasi satu 


\section{JURNAL GERIA}

ISSN : 2614-6347 (Print) 2614-4107 (Online)

\begin{tabular}{l|l|l|l|} 
Vol.2 & No. & September 2019 \\
\hline
\end{tabular}

pihaknya adalah $\frac{0,000}{2}=0$, dengan demikian nilai tersebut kurang dari 0,05 artinya peningkatan kemampuan berpikir logis anak usia dini dengan menggunakan keterampilan proses sains terdapat perbedaan dibandingkan dengan anak yang menggunakan metode pembelajaran konvensional. Hal ini menunjukan bahwa setelah diberikan perlakuan yang berbeda yaitu kelompok eksperimen dengan metode kuasi eksperimen dan kelompok kontrol dengan metode konvensional menunjukkan hasil yang berbeda pada tingkat berpikir logis antara kelompok ekperimen dan kelompok kontrol.

Berdasarkan hasil data pre test dan post test antara kelompok eksperimen dan kelompok kontrol didapatkan hasil uji gain. Hasil uji gain diperoleh dari jumlah data post test dikurang jumlah data pre test, menunjukkan bahwa nilai rata-rata N-Gain skor untuk kelas eksperimen adalah sebesar 0,76148 atau $76,14 \%$ termasuk dalam kategori efektif. Dengan nilai $\mathrm{N}-$ Gain skor minimal 56\% dan maksimal 88,23\%. Sementara untuk rata-rata N-Gain skor untuk kelas kontrol adalah sebesar 0,0560 atau $5,60 \%$ termasuk dalam kategori tidak efektif. Dengan nilai $\mathrm{N}$-Gain skor minimal $2,70 \%$ dan maksimal 14,63\%. Maka dapat disimpulkan bahwa penggunaan keterampilan proses sains efektif untuk meningkatkan kemampuan berpikir logis anak usia dini.

Setelah kedua kelas diberi perlakuan yang berbeda selama delapan kali pertemuan, yaitu kelas eksperimen menggunakan keterampilan proses sains dan kelas kontrol menggunakan pembelajaran biasa (konvensional) diperoleh hasil uji N-Gain yang menunjukkan bahwa kemampuan berpikir logis anak usia dini yang pembelajarannya menggunakan keterampilan proses sains efektif untuk meningkatkan kemampuan berpikir logis

pada anak usia dini. Dengan demikian, analisis perbedaan kemampuan berpikir logis anak usia dini pada kelas eksperimen yang pembelajarannya menggunakan keterampilan proses sains jauh lebih meningkat dibanding kelas kontrol yang mengunakan pembelajaran biasa, walaupun pada hasilnya kelas kontrolpun memiliki peningkatan.

Dengan menggunakan keterampilan proses sains diharapkan anak usia dini dapat memperoleh pengalaman belajar yang menyenangkan, sehingga kemampuan kognitifnya berkembang khususnya kemampuan berpikir kritis dan kreatif, sehingga dapat mengolah perolehan belajarnya, dapat menemukan bermacam-macam alternatif pemecahan masalah, mampu mengembangkan kemampuan logika, pemecahan masalah dan membantu meningkatkan kemampuan berpikir logis (Yulianti, 2010).

\section{Pembahasan}

Berdasarkan hasil analisis yang telah dijelaskan sebelumnya, bahwa hasil tes awal (pre test) kemampuan berpikir logis anak usia dini kelas eksperimen dan kelas kontrol telah terdapat perbedaan yang signifikan menunjukkan bahwa data yang diperoleh dari penelitian di lapangan yaitu nilai kemampuan berpikir logis antara kedua kelas sudah terdapat perbedaan, sehingga harus dilakukan penilaian uji N-Gain skor untuk mengetahui analisis perbedaan peningkatan nilai antara kelas eksperimen dan kelas kontrol.

Setelah kedua kelas diberi perlakuan yang berbeda selama delapan kali pertemuan, yaitu kelas eksperimen menggunakan keterampilan proses sains dan kelas kontrol menggunakan pembelajaran biasa (konvensional) diperoleh hasil uji N-Gain yang menunjukkan bahwa kemampuan berpikir logis anak usia dini yang 


\section{JURNAL GERIA}

ISSN : 2614-6347 (Print) 2614-4107 (Online)

Vol.2 | No.5 | September 2019

pembelajarannya menggunakan keterampilan proses sains efektif untuk meningkatkan kemampuan berpikir logis pada anak usia dini. Dengan demikian, analisis perbedaan kemampuan berpikir logis anak usia dini pada kelas eksperimen yang pembelajarannya menggunakan keterampilan proses sains jauh lebih meningkat dibanding kelas kontrol yang mengunakan pembelajaran biasa, walaupun pada hasilnya kelas kontrolpun memiliki peningkatan.

$$
\text { Dengan menggunakan }
$$

keterampilan proses sains diharapkan anak usia dini dapat memperoleh pengalaman belajar yang menyenangkan, sehingga kemampuan kognitifnya berkembang khususnya kemampuan berpikir kritis dan kreatif, sehingga dapat mengolah perolehan belajarnya, dapat menemukan bermacam-macam alternatif pemecahan masalah, mampu mengembangkan kemampuan logika, pemecahan masalah dan membantu meningkatkan kemampuan berpikir logis (Yulianti, 2010).

Dari hasil pengamatan penelitian, faktor meningkatnya kemampuan berpikir logis anak usia dini dengan menggunakan keterampilan proses sains adalah karena pembelajaran seperti ini dirancang melalui bermain sehingga sangat efektif membuat anak aktif seperti halnya anak belajar bereksperimen, bereksplorasi, dan mengidentifikasi lingkungan sekitarnya sehingga anak sendirilah yang akan membangun pengetahuannya sendiri melalui rasa keingintahuannya yang tinggi. Dengan melakukan percobaan dan menemukan konsep sendiri, anak akan lebih mudah mengingat informasi yang didapat dan tidak mudah lupa. Selain itu karena anak usia dini pada umumnya memiliki dorongan yang kuat untuk mengetahui sesuatu, selalu ingin mencoba hal-hal baru, maka diperlukan media belajar untuk memenuhi kebutuhan anak tersebut, namun upaya peneliti dalam mengaplikasikan keterampilan proses sains adalah untuk membuat strategi atau metode serta bahan atau media yang digunakan harus menarik serta diikuti oleh anak sehingga dengan begitu anak tidak terasa memperoleh konsep sains melalui belajar agar anak dapat memperoleh pembelajaran yang menyenangkan dan bermakna (Yulianti, 2010).

Berdasarkan penelitian yang dilakukan oleh Kurniasari (2017) dengan Judul Penggunaan Media Alam Sekitar dan Kemampuan Berpikir Logis Anak Usia Dini hasil penelitian menunjukkan bahwa ada hubungan yang signifikan antara penggunaan media alam sekitar dengan kemampuan berpikir logis anak usia dini dengan penggunaan uji korelasi SpearmanRank. Penelitian ini bertujuan untuk mengetahui kemampuan kognitif anak usia dini.

Hal ini terbukti pada saat pembelajaran berlangsung dengan beragam kegiatan atau media yang digunakan atau diberikan oleh guru sangat beragam, tidak hanya sekedar teori. Guru mulai paham bahwa pentingngnya pengembangan kemampuan berpikir logis sebagai dasar seseorang menangkap informasi, keingintahuan baru yang didapat, dan dapat menyimpulkan sebagai landasan berpikir seseorang. Pembelajarannya pun dapat dikenalkan dengan sangat menarik seperti melalui bermain atau keterampilan proses sains.

\section{KESIMPULAN}

Kesimpulan hasil penelitian pengaruh keterampilan proses sains terhadap kemampuan berpikir logis pada anak usia dini, dipaparkan sebagai berikut; (1) Dilihat dari penilaian data pre test eksperimen menunjukan bahwa penilaian anak usia dini sudah 


\section{JURNAL GERIA}

ISSN : 2614-6347 (Print) 2614-4107 (Online)

\begin{tabular}{l|l|l|} 
Vol.2 & No.5 & September 2019 \\
\hline
\end{tabular}

berkembang, rata-rata anak berada pada penilaian Berkembang Sesuai Harapan (BSH), kemampuan berpikir logis pre test anak usia dini sudah berkembang, menunjukkan bahwa data yang diperoleh dari penelitian di lapangan yaitu nilai kemampuan berpikir logis antara kedua kelas sudah terdapat perbedaan. (2) Dilihat dari penilaian data post test eksperimen menunjukan bahwa peningkatan kemampuan berpikir logis anak usia dini dengan menggunakan keterampilan proses sains terdapat perbedaan dibandingkan dengan anak yang menggunakan pembelajaran konvensional. (3) Penelitian ini membuktikan bahwa melalui keterampilan proses sains, kemampuan berpikir logis anak pada kelompok eksperimen terdapat perbedaan yang signifikan dibandingkan dengan profil kemampuan berpikir logis anak pada kelompok kontrol yang menggunakan metode konvensional. Hal ini dapat dilihat dari hasil nilai rata-rata gain data pre test dan data post test pada kelompok eksperimen nilai rata-rata gain memiliki hasil lebih besar dibandingkan nilai ratarata gain kelompok kontrol. (4) Implementasi pembelajaran dengan menggunakan keterampilan proses sains sudah terlaksana dengan baik sesuai dengan rencana yang sudah dirancang peneliti, dimana anak usia dini terlihat lebih mengerti dengan pembelajaran. Karena, pada metode ini semua anak terlibat dalam segala prosesnya dan

dapat menyelesaikan dengan baik seperti keterampilan mengobservasi, menggolongkan, mengkomunikasikan, dan memprediksi.

\section{DAFTAR PUSTAKA}

Budiningsih. (2005). Belajar dan Pembelajaran. Jakarta : PT Rineka Cipta.

Kurniasari. (2017). Penggunaan Media Alam dan Kemampuan Berpikir Logis Anak Usia Dini. Tersedia di http://jurnal.fkip.unila.ac.id/index.php/P AUD/article/download/15163/11071. Di akses pada 21 Juli 2019.

Mursid. (2015). Belajar dan Pembelajaran PAUD. Bandung : PT Remaja Rosdakarya.

Mursid. (2016). Pengembangan Pembelajaran PAUD. Bandung : PT Remaja Rosdakarya.

Muslihuddin \& Agustin, M. (2008). Mengenali Dan Mengembangkan Potensi Kecerdasan Jamak Anak Usia Taman Kanak-Kanak Raudhatul Athfal. Bandung : Rizqi Press.

Nugraha, A. (2008). Pengembangan Sains Pada Anak Usia Dini. Bandung : Jilsi Foundation Pembelajaran.

Ruseffendi, E.T. (2010). Dasar-Dasar Penelitian Pendidikan Bidang Non Eksakta lainnya. Bandung: Tarsito.

Susanto, A. (2011). Perkembangan Anak Usia Dini. Jakarta : Kencana.

Yulianti, D. (2010). Bermain Sambil Belajar Sains Di Taman Kanak-Kanak. Jakarta: PT Indeks. 